\title{
Pericardial effusion and cardiac tamponade in a dog with hypothyroidism
}

\author{
Efusión pericárdica y taponamiento cardíaco en un perro con hipotiroidismo \\ J Ojeda*, M Mieres, C Dunner, N Sagredo, H Bustamante \\ Department of Veterinary Clinical Sciences, Faculty of Veterinary Sciences, Universidad Austral de Chile, Valdivia, Chile.
}

\begin{abstract}
RESUMEN
La relación entre hipotiroidismo y enfermedades cardiovasculares en perros frecuentemente está asociada con la presencia de signos clínicos como bradicardia sinusal, alteraciones miocárdicas y complejos QRS de bajo voltaje y onda T invertida en el electrocardiograma. Varios estudios en perros hipotiroideos no han mostrado la presencia de efusión pericárdica, sin embargo, en humanos es bien conocida la presencia de efusión pericárdica asociada a hipotiroidismo, pero el taponamiento cardiaco no es un signo frecuente. Un perro Golden Retriever fue presentado con historial clínico de letargia progresiva, intolerancia al ejercicio, intolerancia al frío y dificultad respiratoria durante 3 semanas. Al examen clínico el perro presentó disnea, tonos cardiacos tenues e hipertensión. El examen ecocardiográfico demostró la presencia de fluido en el saco pericárdico y taponamiento cardiaco. Se realizó una pericardiocentesis y el análisis citológico del fluido descartó la presencia de células neoplásicas. La información entregada por los propietarios, además de la detección de zonas alopécicas en cola y abdomen sumado a la evolución clínica llevó a analizar las hormonas tiroideas, confirmando el hipotiroidismo. Una vez realizadas dos pericardiocentesis y posterior suplementación con hormonas tiroideas clínicos no presentaron recurrencia. Aunque la etiología de la efusión pericárdica no fue confirmada es posible que el hipotiroidismo haya causado la efusión pericárdica, o bien el perro padeció una efusión pericárdica idiopática y coincidentemente hipotiroidismo. Sin embargo, de acuerdo con los signos clínicos descritos y evolución de este caso, se sugiere que aun cuando la efusión pericárdica es un signo no descrito en el hipotiroidismo canino, se debe considerar la evaluación de las hormonas tiroideas en perros con efusión pericárdica idiopática.
\end{abstract}

Palabras clave: hipotiroidismo, efusión pericárdica, taponamiento cardíaco, perros.

\section{SUMMARY}

The relationship between hypothyroidism and cardiovascular diseases in dogs is frequently associated with clinical signs like sinusal bradicardia, myocardial alterations and ECG findings such as low voltage QRS and inverted T wave. Echocardiographic studies in hypothyroid dogs have not identified pericardial effusion. Hypothyroidism in human patients is a well-known cause of pericardial effusion, but cardiac tamponade is not a frequent clinical sign. A Golden Retriever was presented with a clinical history of progressive lethargy, exercise intolerance, cold intolerance and increased respiratory effort for 3 weeks. At the clinical examination the dog presented dyspnea, muffled heart sound and hypertension. Echocardiography showed fluid in the pericardial sac and cardiac tamponade and pericardiocentesis was performed. Analyses of the fluid showed a non-neoplastic etiology. The information given by the owners, the alopecia zones detected in tail and abdomen and the clinical response, led to analise the thyroid hormones, and hypothyroidism was confirmed. Following two pericardiocentesis and levothyroxine supplementation, the effusion resolved. Although the etiology of pericardial effusion was not clear, it is possible that the pericardial effusion had been caused by hypothyroidism or the dog had idiophatic pericardial effusion and coincidental hypothyroidism. However, according to the clinical signs and the evolution of the dog, an evaluation of thyroid hormones in dogs with pericardial effusion must be considered even though pericardial effusion is a non-described sign in canine hypothyroidism.

Key words: hypothyroidism cardiac tamponade, pericardial effusion, dogs.

\section{INTRODUCTION}

Cardiac abnormalities associated to hypothyroidism in dogs are common, but their clinical significance is higher in patients with preexisting cardiac conditions. The relationship between hypothyroidism and cardiovascular diseases in dogs is frequently associated with clinical signs like sinus bradicardia, myocardial alterations and some findings in ECG such as low voltage QRS and inverted T wave. However, echocardiographic studies in hypothyroid dogs do not describe the development of pericardial effusion

Accepted: 23.04.2015.

* javierojeda@uach.cl
(PE) (Flood and Hoover 2009, Panciera 1994, Phillips and Harkin 2003, Sangster et al 2012). The presence of PE in humans with hypothyroidism represents between 3-5\% and it is dependent on severity and duration of hypothyroidism (Chiang et al 2012).

The purpose of this report is to describe an atypical clinical sign of an adult Golden retriever with hypothyroidism that was diagnosed with pericardial effusion and cardiac tamponade.

\section{MATERIAL AND METHODS}

A 5 year old unspayed female Golden Retriever, weighing $37.5 \mathrm{~kg}$, was referred. The dog had presented with a clinical history of weakness, extremely sensitive 


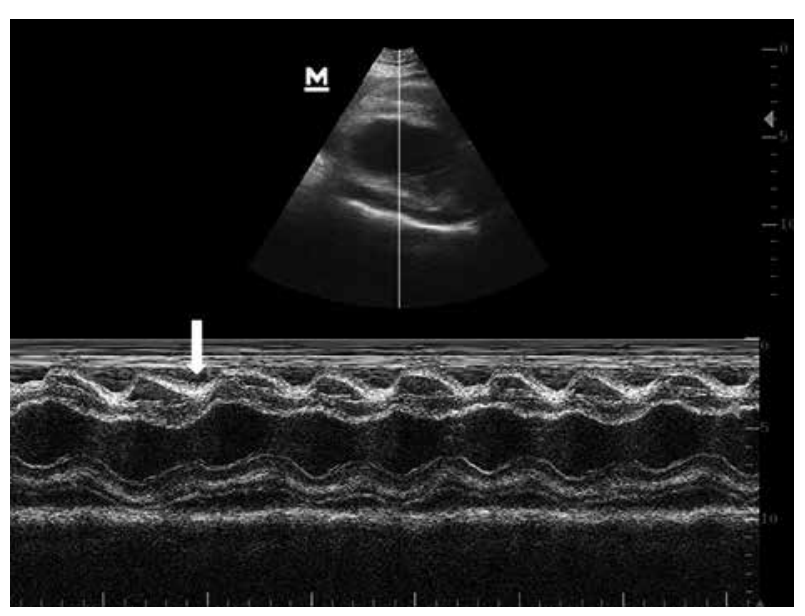

Figure 1. M-mode echocardiography from the right parasternal long axis view. Note the fluid in the pericardial sac before the pericardiocentesis. The diagnosis of cardiac tamponade was made according the collapse of the right ventricular during diastole (arrow).

Eje largo de vista para esternal derecha en modo M ecocardiografico. Se observa fluído en el saco pericárdico previo a la pericardiocentesis. El taponamiento cardíaco fue diagnosticado observando el colapso del ventrículo derecho durante el diástole (flecha).

to cold temperatures, exercise intolerance and increased respiratory effort for 3 weeks. At time of presentation, the dog was quiet and slowly responsive. A marked inspiratory dyspnea, dry and cyanotic mucous membranes, weak femoral pulse and jugular distension were observed. During thoracic auscultation, marked bronchial and vesicular sounds were heard but the intensity of the heartbeat was decreased. Systemic blood pressure values were 200/140 $\mathrm{mmHg}$. Rectal temperature was $36.5^{\circ} \mathrm{C}$ and pulse oximetry was at $76 \%$. The abdomen was distended and tense, indicating the presence of fluid in the abdominal cavity. Also, hyperpigmentation with alopecia on the dorsal neck area, nose and tail was observed. Initial treatment included oxygen supplementation and placement of intravenous catheter to administer medication. The dog was eating and drinking and no hypovolaemic status was detected. An enlarged, globoid shaped cardiac silhouette was observed in thoracic radiographs. Moreover, a diffuse alveolar pattern was observed.

\section{RESULTS AND DISCUSSION}

Echocardiographic findings included pericardial fluid and severe collapse of the right ventricle consistent with cardiac tamponade (figure 1). According to the normal values for Golden Retriever (Morrison et al 1992) a decreased left ventricular systolic diameter $(2.1 \mathrm{~cm})$ and decreased left ventricular diastolic diameter $(3.26 \mathrm{~cm})$ was diagnosed. The shortening fraction was calculated to be approximately $35 \%$. The left atrium:aorta ratio was 1.35 . Abdominal ultrasound detected ascites. Findings were conclusive with cardiac tamponade. Pericardiocentesis was performed and $428 \mathrm{ml}$ of hemorrhagic fluid was removed. An ECG was done before and after pericardiocentesis. Before the pericardiocentesis the ECG showed low voltage QRS and ST complexes and slight electrical alternans on QRS an ST. These findings resolved immediately after the pericardiocentesis (figure 2). Pericardial fluid cytology revealed 13,900 cells/uL and hematocrit of $10 \%$. The observed cells were consistent with pleomorphic reactive mesothelial cells with prominent nucleolus and occasional mitotic figures were detected in some microscopic fields. In contrast, abundant neutrophils and thrombocytes were also present. These findings were associated to aseptic fluid characterised by reactive mesothelial cells. However the mesothelioma was not discarded due to the presence of malignancy features in some cells.

A blood test revealed regenerative normocytic normochromic anemia (PCV 27\%, reference range 37-50\%; MCV $70 \mathrm{fl}$, reference range $60-77 \mathrm{fl}$; MCHC $28.9 \mathrm{~g} / \mathrm{dl}$, reference range $32.0-37.0 \mathrm{~g} / \mathrm{dl})$, and thrombocytopenia $\left(11,2 \times 10^{-3} /\right.$ $\mathrm{ml}$, reference range $177-398^{-3} / \mathrm{ml}$ ). Leukocytosis was observed $\left(29,4 \times 10^{-3} / \mathrm{ml}\right.$ reference range $\left.5,3-19,8 \times 10^{-3} / \mathrm{ml}\right)$

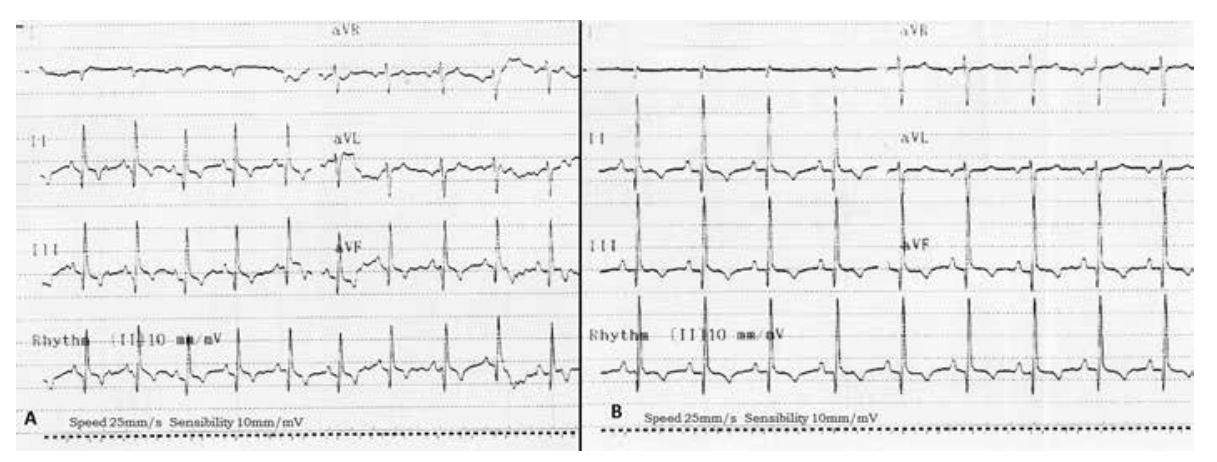

Figure 2. Electrocardiogram showed a low voltage QRS in all leads and slight electrical alternans on QRS and ST complexes, before the first pericardiocentesis (A). Electrocardiogram after the pericardiocentesis (B), QRS complexes increased the voltages without presence of the electrical alternans. Paper speed $25 \mathrm{~mm} / \mathrm{s} ; 1 \mathrm{~cm}=1 \mathrm{mV}$.

El electrocardiograma muestra un bajo voltaje en el complejo QRS en todas las derivadas, además se observa leve alternancia eléctrica en los complejos QRS y ST, antes de realizar la pericardiocentesis (A). 
with moderate neutrophilia $\left(25,5 \times 10^{-3} / \mathrm{ml}\right.$, reference range $\left.3,1-14,4 \times 10^{-3} / \mathrm{ml}\right)$. Biochemical analysis revealed high creatine kinase (220 U/L, reference range $25-125 \mathrm{U} / \mathrm{L}$ ) and mild azotemia (urea nitrogen $55 \mathrm{mg} / \mathrm{dl}$, reference range 5-30 $\mathrm{mg} / \mathrm{dl}$, creatinine $3.1 \mathrm{mg} / \mathrm{dl}$, reference range $0.7-1.8 \mathrm{mg} / \mathrm{dl}$ ).

Clinical findings, laboratory results and echocardiography confirmed the diagnosis of pericardial effusion. According to the findings, the most suggestive diagnosis was idiophatic pericardial effusion.

After 24 hours the dog showed a marked improvement. Seven days after initial treatment the ascites disappeared but still the dyspnea and arterial hypertension (190/140) persisted. A treatment with $0.5 \mathrm{mg} / \mathrm{kg}$ enalapril orally twice a day and oxygen $(5 \mathrm{~L} / \mathrm{min})$ was initiated. The hematological parameters worsered, a severe neutrophilia (neutrophils $4937310^{-3} / \mathrm{ml}$ reference range 3300-10000 $10^{-3} / \mathrm{ml}$ ) was detected. Thoracic radiographics showed a persistence of alveolar pattern. Therefore, secondary bacterial contamination of pulmonary tissue was associated with this possibly due to pulmonary congestion or intubation procedure. Antibacterial therapy was initiated using $20 \mathrm{mg} / \mathrm{kg}$ Amoxicillin/ clavulanic acid orally twice a day. Moreover, azotemia increased (Urea nitrogen 70 $\mathrm{mg} / \mathrm{dl}$, reference range $5-30 \mathrm{mg} / \mathrm{dl}$; Creatinine $4.7 \mathrm{mg} /$ $\mathrm{dl}$, reference range $0.7-1.8 \mathrm{mg} / \mathrm{dl}$ ) with a marked hyperphosphatemia $(8.43 \mathrm{mg} / \mathrm{dl}$, reference range $2.8-6.1 \mathrm{mg} /$ dl) possibly associated to a decreased renal blood flow due to hypertensión. Intravenous maintenance fluid was maintained and diuresis therapy with furosemide $2 \mathrm{mg} / \mathrm{kg}$ orally twice a day was incluided. On day 15 , although blood pressure and body temperature were normal and respiratory signs and renal function improved the dog remained cold intolerance. Radiographs findings showed cardiomegaly with a globoid shape but less than the first radiography approach. Echocardiography showed cardiac tamponade again. A second pericardiocentesis was performed and $196 \mathrm{ml}$ of the reddnish fluid was removed containing 2700 cells/uL and hematocrit at $4 \%$. Fluid analysis contained $5.2 \mathrm{~g} / \mathrm{dl}$ of total protein, $\mathrm{pH} 7.0$ and glucose $150 \mathrm{mg} / \mathrm{dl}$. Cytological analysis showed monocytes (95\%), neutrophils (5\%) and a light red background. At the same time, blood samples were collected that showed that hematological and biochemical parameters were abnormal. Anemia still was present but the leukocytosis was resolved. Cholesterol, glucose, albumin and triglycerides were higher than reference values. Because of this thyroid hormones were measured ${ }^{1}$. The results showed decreased values of $\mathrm{T} 4 \mathrm{t}$ and T4f (T4 $0.5 \mathrm{ug} / \mathrm{dl}$, reference range 1.3-3.8 ug/dl; T4f 0,2 $\mathrm{pg} / \mathrm{dl}$, reference range $0,3-1,3 \mathrm{pg} / \mathrm{dl}$ ) with increased cTSH $(1.0 \mathrm{ng} / \mathrm{ml}$, reference range $<0,6 \mathrm{ng} / \mathrm{ml})$. Based on clinical signs, clinical pathological findings and thyroid hormones, primary hypothyroidism was diagnosed. At day 20 , after the first pericardiocentesis, the thoracic radiographs and echocardiography were normal. For this reason the dog was

Immulite canine immunoassay, Siemens Health Care. discharged. Oral treatment with Levothyroxine at dosage of $0.02 \mathrm{mg} / \mathrm{kg}$ q $12 \mathrm{~h}$, furosemide ( $3 \mathrm{mg} / \mathrm{kg} / \mathrm{q} 12 \mathrm{~h}$ ) and enalapril $(0,5 \mathrm{mg} / \mathrm{kg} / \mathrm{q} 12 \mathrm{~h})$ were recommended. Thyroid hormones were normal (T4t 2,1 ug/dl, T4f 0,9 pg/dl, TSH 0,5ng/dl) on day 60 and the cutaneous signs improved totally on day 120. Within 8 months of hormonal supplementation and monthly echocardiographic monitoring, the presences of pericardial effusion, heart tumor or new cardiovascular signs did not develop.

Pericardial diseases (PD) represent nearly $8 \%$ of all cardiovascular disorders. Most dogs with PD develop pericardial effusion (PE) as a common clinical sign (Shaw and Rush $2007^{\mathrm{a}}$ ). PE is frequently associated as a consequence of cardiac neoplasias or the idiopathic form representing $58 \%$ and $19 \%$, respectively (Stafford et al 2004). PE associated to hypothyroidism is a rare condition in dogs but it has been previously described in humans (Chiang et al 2012, Cohen et al 2012, MacGregor et al 2004). Reports of PD in dogs with hypothyroidism are scarce. Only a single report describes cholesterol-based pericardial effusion in a dog with hypothyroidism, where other different causes could not be ruled out (MacGregor et al 2004).

The clinical signs described in the present report were muffled heart sounds, jugular venous distention, poor pulse quality, ascites, lethargy and exercise intolerance. These signs are frequently reported in dogs with cardiac tamponade (Shaw and Rush 2007ª, Stafford et al 2004).

Cardiac tamponade was diagnosed and considered an emergency and pericardiocentesis was immediately performed. After pericardiocentesis the dog improved its clinical and electrocardiographic parameters but the pericardial effusion recurred albeit to a lesser degree than at presentation. The hypertension did not resolve after the initial pericardiocentesis, so furosemide and enalapril were administered until the hypothyroidism had resolved with levothyroxine supplementation. Until now hypertension had not been reported in hypothyroid dogs as a clinical sign. However in humans many studies have reported a high prevalence of hypertension in hypothyroidism. In the case of cardiac tamponade with hypothyroidism, the hypertension could be explained by a possible excessive adrenergic drive caused by the tamponade (Cohen et al 2012). Also, increased peripheral vascular resistance and low cardiac output have been suggested to be the possible link between hypothyroidism and diastolic hypertension. Also, T3 deficit has been associated with peripheral vasoconstriction and the renin level is reduced in hypothyroid patients (Stabouli et al 2010).

Although the use of furosemide is not recommended as management of cardiac tamponade because it can reduce cardiac filling pressure and thus lower cardiac output (Ware 2009), we justified it use due to persisted hypertension. Moreover, the furosemide treatment was administered while the dog developed the second tamponade, and the severe hypotension described as a potential complication was not detected. 
After the second pericardiocentesis, with Levothyroxine supplementation, no pericardial fluid was subsequently collected. However, in this report is not possible to confirm clearly that the pericardial effusion was attributed to hypothyroidism, mainly because golden retrievers have a significantly increased risk for development pericardial effusion and hypothyroidism. Therefore, it is probably that the pericardial effusion was caused by hypothyroidism or the dog had idiopathic pericardial effusion and coincidental hypothyroidism.

Cytological studies described that the cytological features of the recurrent effusion differed during the course of the disease. Therefore, cytological findings must be associated with clinical signs present in the dog (Cagle et al 2014,Stepien et al 2000). However, the diagnostic possibilities using cytology are varied but increase when the pericardial fluid has a hematocrit $<10 \%$ (Cagle et al 2014, de Lafourcade et al 2007). In humans, pericardial fluid from hypothyroid cardiac tamponade patients is typically an effusion with a color yellowish, with lymphocites and hematocrit $<10 \%$, although the serosanguinous fluid has been reported. The protein content oscillate between 5.0 and $6.2 \mathrm{mg} / \mathrm{dl}$. Also, in cytological examination the presence of mononuclear cells or reactive mesothelial cells is uncommon. This allows to rule out easily some neoplastic diagnoses.

In our case the cytological findings showed reactive mesothelial cells with the first pericardial fluid removed but the hematocrit was 10\%. In the second sample of fluid removed the hematocrit was $4 \%$ and mesothelial cells were not detected and the protein was $5,2 \mathrm{mg} / \mathrm{dl}$. Therefore, the second and last effusion was a modified transudate. But, the definitive non neoplastic diagnosis was made using echocardiographic checkups during 8 months ruled out the presence of pericardial disease. Retrospective echocardiographic studies detected that $60 \%$ of the dogs with idiopathic pericardial effusion have reactive mesothelial cells without echocardiographic evidence of mesotheliomas during a period at more than 120 days (MacGregor et al 2004, Rajagopalan et al 2013, Stepien et al 2000).

A diagnosis of hypothyroidism in this dog was suspected based on typical clinical signs such as chronic lethargy described by the owners, nasal and tail alopecia, cold intolerance, also non regenerative mild anemia and hypercholesterolemia (Panciera 1994).

The diagnosis was confirmed with T4 and TSH screenings. In humans hypothyroidism is thought to result in increased capillary permeability and impaired lymphatic drainage with protein leakage into the interstitial space, resulting in PE. Furthermore, hypothyroidism causes salt and water retention (Lin et al 2000). For these reasons, hypothyroidism in human patients is a well-known cause of PE, but cardiac tamponade is not a frequent clinical sign. Echocardiography in humans diagnosed early with hypothyroidism, identifies $\mathrm{PE}$ in $3-5 \%$ cases. The PE is minimal, representing $<5 \mathrm{~mm}$ of the $\mathrm{M}$ mode width and no more than $200 \mathrm{ml}$ of fluid collected (Lin et al 2000). In dogs, the velocity at which the fluid accumulates is more important than the total volume accumulated to cause tamponade. (Cohen et al 2012, Lin et al 2000, Shaw and Rush 2007 , Stafford et al 2004). Finally the hypothyroidism may have caused the effusion, but is more likely that idiopathic PE did. Unfortunately, there is no way to prove either of them. However, the thyroid hormone supplementation in this case was not associated to a third pericardial fluid collection (Chiang et al 2012, Cohen et al 2012, MacGregor et al 2004). The evaluation of thyroid hormones in dogs with pericardial effusion must be considered.

\section{REFERENCES}

Cagle LA, SE Epstein, SD Owens, MS Mellema, K Hopper, A Burton. 2014. Diagnostic yield of cytologic analysis of pericardial effusion in dogs. $J$ Vet Intern Med 28, 66-71.

Chiang WF, KA Wu, KY Liu, BY Liu. 2012. Hypovolemia-induced cardiac tamponade in a patient with hypothyroidism. J Emerg Med 43, e409-e412.

Cohen R, P Loarte, S Opris, B Mirrer. 2012. Cardiac tamponade as the initial manifestation of severe hypothyroidism: A case report. WJCD 2, 321-325.

Flood JA, JP Hoover. 2009. Improvement in myocardial dysfunction in a hypothyroid dog. Can Vet J 50, 828-834.

de Laforcade AM, LM Freeman, EA Rozanski, JE Rush. 2007. Biochemical analysis of pericardial fluid and whole blood in dogs with pericardial effusion. J Vet Intern Med 21, 1002-1007.

Lin CT, CJ Liu, TK Lin, CW Chen, BC Chen, CL Lin. 2000. Myxedema associated with cardiac tamponade. Jpn Heart J 44, 447-450.

MacGregor JM, EA Rozanski, RJ McCarthy, LC Sharkey, MD Winter. 2004. Cholesterol-based pericardial effusion and aortic thromboembolism in a 9-year-old mixed-breed dog with hypothyroidism. $J$ Vet Intern Med 18, 354-358.

Machida N, R Tanaka, N Takemura, Y Fujii, A Ueno, K Mitsumori. 2004. Development of pericardial mesothelioma in golden retrievers with a long-term history of idiopathic haemorrhagic pericardial effusion. J Comp Pathol 131, 166-175.

Morrison SA, NS Moise, J Scarlett, H Mohammed, AE Yeager. 1992. Effect of breed and body weight on echocardiographic values in four breeds of dogs of differing somatotype. J Vet Intern Med 6, 220-224.

Panciera D. Hypothyroidism in dogs: 66 cases (1987-1992). 1994. J Am Vet Med Assoc 204, 761-767.

Phillips DE, KR Harkin. 2003. Hypothyroidism and myocardial failure in two Great Danes. J Am Anim Hosp Assoc 39, 133-137.

Rajagopalan V, SA Jesty, LE Craig, R Gompf. 2013. Comparison of presumptive echocardiographic and definitive diagnoses of cardiac tumors in dogs. J Vet Intern Med 27, 1092-1096.

Sangster J, D Panciera, J Abbott. 2012. Cardiovascular effects of thyroid disease. Compend Contin Educ Vet 35, E5-E9.

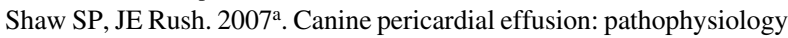
and cause. Compend Contin Educ Vet 29, 400-403.

Shaw SP, JE Rush. 2007 . Canine pericardial effusion: diagnosis, treatment, and prognosis. Compend Contin Educ Vet 29, 405-411.

Stabouli S, S Papakatsika, V Kotsis. 2010. Hypothyroidism and hypertension. Expert Rev Cardiovasc Ther 8, 1559-1565.

Stafford Johnson M, M Martin, S Binns, MJ Day. 2004. A retrospective study of clinical findings, treatment and outcome in 143 dogs with pericardial effusion. J Small Anim Pract 45, 546-552.

Stepien R, NT Whitley, RR Dubielzig. 2000. Idiopathic or mesotheliomarelated pericardial effusion: clinical findings and survival in $17 \mathrm{dogs}$ studied retrospectively. J Small Anim Pract 41, 342-347.

Ware W. 2009. Cardiac tamponade and pericardiocentesis. In: Silverstein D, Hopper K (eds). Small Animal Critical Care Medicine. Saunders Elsevier, St Louis, Mo, USA. 